\title{
Cannes 2005 Report
}

\author{
By Ron Holloway
}

Fall 2005 Issue of KINEMA

\section{A Word from the President}

On the closing night of the 58th edition of the Festival de Cannes (11-22 May 2005), when president Gilles Jacob was asked to comment on the highlights of what was generally touted in the press and media as the most memorable festival in history, he promptly laid his cards on the table.

"This year's Cannes will be remembered for breaking a lot of records: attendance, participation, guests, accreditations, you name it. Not all the facts and figures are in as yet, but we are fully aware of the emergence of a new style of international film festival."

Pushed a bit further, he concluded: "This is the opposite of what André Malraux once said. We have shown that the industry of cinema is also an art."

Asked about further expansion plans, Jacob countered with a shrug: "The idea is not to expand any more," he said. "If we were to expand even more, then the facilities would be less easy to manage."

He also appended this afterthought: "Furthermore, we have no plans to add new sections to those already in place."

Asked what made this year's festival memorable on a personal level, he waxed eloquent on "two beautiful moments." The first was that Sunday afternoon in the Grand Théâtre Lumière - namely: "the séance des enfants, for young kings, 2000 kids, who received the magic of cinema during this screening."

The other memorable moment for a festival president known for his commitment to film heritage, was "the final fireworks dedicated to Federico Fellini and Nino Rota - an absolute delight!"

\section{Official Programme}

With 22 films competing for the Golden Palm, in addition to 14 entries running Out-of-Competition, plus 23 films in the backup Un Certain Regard section, there was less reason than ever before for the faithful to venture out of the Palais des Festivals to seek movie pleasure elsewhere on the Croisette. To make matters even more complicated, the Official Program was packed into ten screening days, leaving the last two days open for reruns of Un Certain Regard entries and Competition favourites. When artistic director Thierry Frémaux scheduled the three top winners for repeat screenings in the Grand Théâtre Lumière in the correct order of their award lineup on the day before they were so honoured at the gala awards ceremonies - JeanPierre and Luc Dardenne's L'Enfant (The Child, Golden Palm), Jim Jarmusch's Broken Flowers (Grand Prize), and Michael Haneke's Caché (Hidden, Best Director) - he simply followed the lead of critics on the voting charts.

One predominant trend was noted at this year's Cannes festival. Thierry Frémaux clearly showed a preference for the works of veteran directors who had previously made a name for themselves at Cannes. Thus, instead of an emphasis on emerging talent from Asia and Latin America, as was the case last year, priority was given to such name directors as Jean-Pierre and Luc Dardennes, Jim Jarmusch, Michael Haneke, Lars von Trier (Manderlay), Gus van Sant (Last Days), Hou Hsiao-hsien (Three Times), Amos Gitai (Free Zone), David Cronenberg (A History of Violence), Wim Wenders (Don't Come Knocking), and Atom Egoyan (Where the Truth Lies), plus Woody Allen (Match Point) and George Lucas (Star Wars - Episode III) in out-ofcompetition slots. As for the predominant theme in the Competition, it was about fathers seeking lost sons (Dardenne Brothers, Jarmusch, Wenders), or about people simply broken off from family ties (van Sant, Haneke, Gitai).

\section{Palme d'Or Deux}

The circle of double winners of the Palme d'Or widened when Jean-Pierre and Luc Dardenne (awarded the Golden Palm in 1999 for Rosetta) joined Francis Ford Coppola (The Conversation, 1974, Apocalypse Now, 1979), Shohei Imamura (The Ballad of Narayama, 1983, The Eel, 1997), Emir Kusturica (When Father's 
Away on Business, 1985, Underground, 1995), and Bille August (Pelle the Conqueror, 1988, Best Intentions, 1992) to become the fifth member of this rather exclusive club. On the other hand, the Belgian directors of L'Enfant ( The Child) are hardly strangers to Cannes. Their La Promesse (The Promise), the story of a youth who rebels against an abusive father, was programmed in the Directors Fortnight at the 1996 Cannes festival, and from there it went on to win a bundle of awards at international festivals. In Rosetta an 18-year-old girl by fighting for any menial job she can get. In Le Fils (The Son), an official entry at the 2002 Cannes festival, a carpentry teacher in a trade school is confronted by the youth who had unintentionally killed his son. For his performance as a simple working-man wrestling with his own conscience, Olivier Gourmet was awarded Best Actor.

In L'Enfant the focus is on a young street-couple barely out of their teens who are the parents of a new-born baby - she happily, he just the opposite. When Bruno (Jérémie Renier) hits upon the idea of selling the baby to a mafia band, the decision crushes Sonia (Déborah François). The hyper-sensitive mother collapses on the spot, and is committed to a hospital. Bruno's attempts to get the baby back lead to more calamities - until he finally awakens to the consequences of his actions. Asked where the idea for L'Enfant came from, the Dardennes responded: "From the streets. One day, we saw a young man wheeling a baby-buggy around the city, aimlessly, from corner to corner. From there we constructed a frame for the story." A docu-drama about losers in the social system, L'Enfant raises as many questions as it hints of answers. But non-professional actors imbue this slice-of-life story with a cutting-edge intensity you don't find in conventional social dramas.

\section{Near Misses}

The American entries, Jim Jarmusch's Broken Flowers and Tommy Lee Jones's The Three Burials of Melquiades Estrada, stood head-high over the competition entries and deserved a bit more than they got from the jury. Broken Flowers, awarded the Grand Jury Prize, features a deadpan Bill Murray as a retired Don Juan whose latest girlfriend (Julie Delpy) is about to leave him. Nudged from his indolence by a mysterious pink letter that informs him of the probable arrival of a "fatherless" 19-year-old son, the news leaves him wondering which of his old flames had sent the letter. But thanks to a persistent neighbour, who supplies him with a list of old girlfriends, he sets out on an odyssey across the country to meet the women in question: Sharon Stone, Frances Conroy, Jessica Lange, and Tilda Swinton. A hilarious comedy that still has you laughing as you leave the theatre, Broken Flowers is as much Bill Murray's film as it is Jarmusch's. "I didn't have many lines," said Murray at the press conference. "All I had to do was to react to the beatings I got from the women."

As for The Three Burials of Melquiades Estrada, for which Tommy Lee Jones was awarded Best Actor and Mexican novelist-scriptwriter Guillermo Arriaga (Amores Perros, 21 Grams) the award for Best Screenplay, the film confirmed Jones as a budding directorial talent as well. Jones plays a ranch foreman with a trigger temperament. His friendship with a Mexican wetback on the ranch - "Melquiades (Julio Cesar Cedillo) is one good Mexican" - prompts him to take revenge on a guilty border guard (Barry Pepper) who had killed the wetback by accident and then buried him on the spot. After the second burial in the town cemetery, Jones digs the body up again and sets out, with the killer in tow, on a journey of expiation across the border to a place that, in the end, exists only in the dead man's imagination. Shot partially on the open desert range of Jones's own ranch in West Texas, the film benefits from its magnificent cinematography (Chris Menges), in which the landscape plays an integrating role in this meandering tale of moral atonement.

\section{Funny Video Games}

"Victims interest me more than perpetrators," said Michael Haneke on the making of La Pianiste (The Piano Teacher, 2001). "Women are more interesting because they're further down the line in the pecking order. Men bore me." So why is the victim in Haneke's Hidden a man? Dig a big further, however, and you discover in Hidden that the victim had once been a perpetrator himself. Georges (Daniel Auteuil), a noted literary guru on French television receives a mysterious videotape that could only come from a person who knows him like a book. As the story unfolds, and more tapes arrive, his wife (Juliette Binoche) is drawn into the riddle of a hidden secret in the man's life. Disturbing dreams and flashbacks reveal that Georges in his childhood had committed a grievous offence against an orphaned Algerian boy who was living in the family 
house. That's about as far as the psycho-thriller goes, for the rest is little more than a teasing psychogram of a man's nagging conscience. Awarded Best Director at Cannes, backed up by FIPRESCI and Ecumenical Prizes, Hidden was also the favourite of French critics for the Palme d'Or.

Ever since his Funny Games drove viewers from their seats at the 1997 Cannes festival, Haneke has found an artistic home in France. A weird tale about a pair of murderous psychopaths toying with their victims before killing them, Funny Games was followed a year later by the more accessible Code inconnu (Code Unknown), starring Juliette Binoche as the standard Haneke victim. On the surface a chronicle about the socially alienated and the psychologically disturbed peopling the streets and metros of Paris, Code Unknown offers a harsh portrait of urban ethics found in European capitals. He said in an interview that he wanted the audience to feel the coldness of the consumer society, the incapacity of social classes to intercommunicate, the fears emanating from xenophobia and prejudice, the Babylonian confusion of languages, and the media's clichés about winners and the losers. That same aesthetic was followed in Hidden, only this time the ethical, moral, and psychological issues are transferred entirely to the mind of the viewer. For those cineastes looking for a hidden link between Caché and Haneke films of the past, then try Benny's Video (1992). In that film, as well as in Hidden, the couple's teenaged son is rarely seen without a trusty video gun in his hand.

\section{Mythical America}

No other director worked as hard as Wim Wenders to win the Palme d'Or. The same is true of Lars von Trier, save that the Danish director works just as hard to give the impression that he couldn't care less. Both had won the Golden Palm before: Wenders for Paris, Texas (1984), Trier for Dancer in the Dark (2000). Both films had been set in a mythical America of their own creation. Wenders returned to Cannes this year with Don't Come Knocking (Germany-France), a kind of update of Paris, Texas, according to press releases leading up to the festival. Wenders appeared on the front page of the Le Monde edition for and about the Cannes entries. The prestigious German weekly, Die Zeit, featured Wim's own remembrances of his many visits to Cannes, particularly the night he played flipper ("to calm my nerves") on a pin-ball machine in the Petit Carlton Bar on the night of the Paris, Texas premiere two decades ago. Even Sam Shepard was back, not just as screenwriter but this time as Howard Spence, the burnt-out Western star who gallops off the set in the middle of production. All to no avail. Don't Come Knocking was passed over completely by the Cannes jury. With good reason: shot partially in Moab, Utah (John Ford country), partially in Butte, Montana (Dashiell Hammett country), it comes across as a backlot Western - a film of pretence and pretending, one without much depth or any visible purpose.

Lars von Trier's Mandalay (Denmark-Sweden-Netherlands-UK), the second episode of his heralded American trilogy, is supposedly set on a Southern plantation, named Mandalay, in 1933. Filmed again on that blacklacquered floor in an abandoned Swedish machine factory, painted with the names of streets and buildings to identify locations, it's the same set he used for Dogville (Cannes, 2003). As for its thematic focus, let's just say that there is evil lurking behind the facade of this American community in Alabama, the same as came to the surface in his Rocky Mountain tale set in the mythical town Dogville. Here, the slave trade in the cotton fields hasn't changed much in the 70 years since Abe Lincoln proclaimed their emancipation - in fact, the slaves seem to like it this way. Shot with a shaky digital camera (apparently an auteur aesthetic), Mandalay picks up where Grace (Bryce Dallas Howard, instead of Nicole Kidman) left off in Dogville - who is left on her own again by her gangster father (Willem Dafoe, instead of James Caan) and tries in her own timid but determined way to right the wrongs perpetrated on a blind humanity in an otherwise unjust world. In the end, of course, she loses. As for the third part of the trilogy, we may have to wait a couple years. Lars von Trier announced at Cannes that he wants to take time to shoot another kind of movie.

\section{Tone Poems}

Several entries at Cannes defy description. Gus van Sant's Last Days (USA) comes across as the end piece in a HBO trilogy of "tone poems" about the distortions in modern American culture. Shortly to be programmed at the Museum of Modern Art, the trilogy began with Gerry (2002), about two youths wandering aimlessly in the desert. It was followed by Elephant (Cannes, Palme d'Or, 2003), about the Columbine high school massacre. And now it is topped by a film that deals with the tragic death of Kurt Cobain, the recording star who died from an overdose. 
According to a statement by Hou Hsiao-hsien, his Three Times (Taiwan) is a "chant of love" set in three periods of time - 1911, 1966, 2005 - in a trilogy of similar stories starring the same actors (Shu Qi and Chang Chen). The 1911 episode, the centre-piece of the film, is presented as a would-be silent movie with the dialogue rendered in intertitles. The idea is to pay homage to the bliss of memories and those unforgettable moments now lost forever.

Amos Gitai's Free Zone (Israel-France-Spain-Belgium) is a journey that three women of different cultures and background take in a van from Jerusalem to the so-called "Free Zone" in Jordan. Nothing much happens in the story, save that the trip is being made to pick up a bundle of money owed to Hanna (Hanna Laszlo, an Israeli, by her husband's partner ("the American"). Along the way, Hanna is joined by Rebecca (Nathalie Portman), an American with a Jewish father but minus the required Jewish mother to be a true Israeli, has just broken off her engagement with her boyfriend and simply wants to get out of the country. And Leila (Carmen Maura), a Palestinian, joins the circle to explain why the money has simply disappeared. Hanna Laszlo, given most of the dialogue in this talking-head drama of politics and survival in a time and place beyond the reach of most in the audience, was awarded Best Actress at Cannes.

Finally, there was Carlos Reygadas's intriguing though disturbing Batalla en el cielo (Battle in Heaven, Mexico), a poetic film of such extremes of visual and verbal vulgarity that it is saved from the label of outright pornography only by the aesthetics of daring cinematic creativity. Reygadas's first feature, Japòn (Mexico-Spain), a Directors Fortnight entry at 2002 Cannes festival, received a special mention in the Camera d'Or competition, thus confirming him as a director to watch. In Battle in Heaven he attacks such institutions as the church, the military, and the state in a tale of sex and violence. Marcos (Marcos Hernandez), a simple man who chauffeurs a general and obeys every wish of his promiscuous daughter, kidnaps a neighbour's child for ransom and is then troubled when the child accidentally dies. In his fumbling search to clear his conscience, he confesses his crime to Ana (Anapola Mushkadiz), the general's daughter, whose sexual appetites he has been satisfying upon request. It leads to a crime greater than the first. This ongoing "battle in heaven" is played out against a background of worship on the Feast of Our Lady of Guadalupe.

\section{PRIZES AND AWARDS}

\section{Official Competition}

- Palme d'Or: L'Enfant (The Child, Belgium), Jean-Pierre and Luc Dardenne

- Grand Prix: Broken Flowers (USA), Jim Jarmusch

- Best Director: Michael Haneke, Caché (Hidden, France-Austria-Germany-Italy)

- Best Screenplay: Guillermo Arriaga, The Three Burials of Melquiades Estrada (USA), dir Tommy Lee Jones

- Best Actress: Hanna Laszlo, Free Zone (Israel), dir Amos Gitai

- Best Actor: Tommy Lee Jones, The Three Burials of Melquiades Estrada (USA), dir Tommy Lee Jones

- Jury Prize: Shanghai Dreams (China), Wang Xiaoshuai

\section{Short Film Awards}

- Palme d'Or: Podorozhini (Wayfarers, Ukraine), Igor Strembitskyy

- Jury Prize: Clara (Australia), Van Sowerwine (animation)

Caméra d'Or (ex aequo)

- Me and You and Everyone We Know (USA), Miranda July (Critics Week)

- Sulanga Enu Pinisa (The Forsaken Land, Sri Lanka-France), Vimukthi Jayasundara (Un Certain Regard)

\section{Cinéfondation Awards}

- First Prize: Buy It Now (USA), Antonio Campos

- Second Prize: (ex aequo) Vdvoyom (A Deux, France), Nikolay Khomeriki, and Bikur Holim (Visiting Hours, Israel), Maya Dreifuss 
- Third Prize: (ex aequo) La plaine (The Field, France), Roland Edzard, and Be Quiet (USA), Sameh Zoabi

\section{OTHER AWARDS}

- Prix Vulcain (Technical Award) Leslie Shatz, for sound design on Last Days (USA), dir Gus van Sant, and Robert Rodriquez, for visual treatment on Sin City (USA), dir Robert Rodriquez

International Critics (FIPRESCI) Awards:

- Competition: Caché (Hidden, France-Austria-Germany-Italy), Michael Haneke

- Un Certain Regard: Sangre (Mexico), Amat Escalante

- Directors Fortnight: Ju-meok-i-woon-da (Crying Fist, South Korea), Ryoo Seung-wan

Ecumenical Award

- Caché (Hidden, France-Austria-Germany-Italy), Michael Haneke

Special Mention

- Delwende (Get Up and Walk, Burkina Faso-France-Switzerland), S. Pierre Yameogo

\section{UN CERTAIN REGARD AWARDS}

- Prix Un Certain Regard: Moartea Domnului Lazarescu (The Death of Mr. Lazarescu, Romania), Cristi Puiu

- Prix de l'Intimité Le Filmeur (Filmman, France), Alain Cavalier

- Pris de l'Espoir Delwende (Get Up and Walk, Burkina Faso-France-Switzerland), S. Pierre Yameogo

\section{DIRECTORS FORTNIGHT AWARDS}

- Carosse d'Or (Award of Honor by Film Directors Society): Ousmane Sembene

- 3ème Label Europa Cinéma (Award to European film for distribution in Europe): La Moustache (France), Emmanuel Carrère

- Prix Art \& Essai CICAE (Arthouse Award): Sisters In Law (UK), Kim Longinotto, Florence Ayisi

- 3ème Prix Regards Jeunes: Alice (Portugal), Marco Martins

- Mention spéciale des Cinémas de Recherche: Odette (Portugal), João Pedro Rodrigues

- Prix SACD du court métrage: Du soleil en hiver (France), Samuel Collardey

- Prix Gras Savoye: À bras le corps (France), Katell Quillévéré

\section{CRITICS' WEEK AWARDS}

- Grand Prix \& Caméra d'Or: Me and You and Everyone We Know (USA), Miranda July

- Prix SACD (ex aequo): Unmei Janai Hito (A Stranger of Mine, Japan), Uchida Kenji, and La Petite Jérusalem (Little Jerusalem, France), Karin Albou

- ACID Award: Mang Zhong (Grain in Ear, China-South Korea), Zhang Lu

- Canal + Award for Best Short Film : Jona / Tomberry (Netherlands), Rosto

- Kodak Discovery Award for Best Short Film : Respire (Taiwan), Wi Ding Ho

- TV5 (Very) Young Critic Award for Best Short Film: Respire (Taiwan), Wi Ding Ho

- TV5 (Very) Young Critic Award for Best Feature Film (ex aequo): Unmei Janai Hito (A Stranger of Mine, Japan), Ushida Kenji, and Me and You and Everyone We Know (USA), Miranda July

- TV5 Award for Best French Critic: Ombline Ley, Laura Jude, Mathieu Bossy of Lycée Bristol de Cannes for Critique of Mang Zhong (Grain in Ear, China-South Korea), dir Zhang Lu

- TV5 Award for Best German Critic: Alexander Koch, Mira Möll et Anjana Siwert of FriedrichMagnus Gesamtschule Laubach for their critique of Unmei Janai Hito (A Stranger of Mine, Japan), dir Ushida Kenji

\section{OTHER PRIZES}

- Prize Regards Jeunes for Best Feature Film: Me and You and Everyone We Know (USA), Miranda July 
- Petit Rail d'Or for Best Short Film: Imago (France-Belgium), Cédric Babouche

- Rail d'Or for Best Feature Film: Unmei Janai Hito (A Stranger of Mine, Japan), Ushida Kenji

\section{Cannes Sidebars - Where the Action Was?}

"You can always find films in the sidebars that are better than the worst films in the competition" - ran the flip statement of a veteran critic in a trade newspaper at the close of the this year's Cannes film festival.

Taken at face value, there is nothing new in this offhand conjecture. Year after year, the favourite game of critics on the Riviera is to pour their likes and dislikes, their largesse and enmity, into the voting lists and roundup reports. It's a way to let off steam, to second-guess the programmers, to slam a film in the competition by praising a discovery in a sidebar.

But which sidebar?

Altogether, there were a half-dozen sidebars at the updated $58^{\text {th }}$ Cannes Festival, to wit: Out-of-Competition and Special Screenings (15 entries), Un Certain Regard (23 entries), Directors Fortnight (21 entries), Week of the Critics (15 entries), Cannes Classics (31 entries), Short Films and La Cinéfondation (27 entries, both section under the same jury).

This lineup does not include a half-dozen more adjuncts - those films and events programmed autour de la sélection (around the official selection), as noted in the catalogue. Thus festivaliers were confronted with another bundle of attractive choices: Tous les cinémas du monde, or World Cinemas (focusing this year on seven invited filmlands), L'atelier du festival, or Festival Atelier (18 young filmmakers), La séance des enfants, or The Children's Screening (French director Michel Ocelot's Kirikou), La leçon de cinéma, or Cinema Master Class (conducted by Senegal's Ousmane Sembene), La leçon d'actrice, or Acting Master Class (conducted by French starlet Catherine Deneuve), Musique à Cannes, or Music in Cannes (with Music Master Class conducted by British composer Patrick Doyle), La journée d'Europe, or Europe Day (a gathering of 25 European cultural ministers), and the indispensable Marché du film, Cannes Film Market.

Furthermore, since the Directors Fortnight and the Week of the Critics programmed shorts and restored prints in their respective programs, as well as feature films and master classes of their own liking, the term "sidebar" now seems entirely out of fashion. Rather, they were "festival events" with a distinct profile and a growing clientele of followers, thanks to some extend to the benefices of the internet. The same can be said of the Cannes Classics program - indeed, the most exciting "sidebar" at this year's Cannes festival.

\section{Cannes Classics}

"Ask the professed cineastes in our audience if they could note the difference between a digital projection and the screening of a restored $35 \mathrm{~mm}$ print, and most would not be able to make the distinction," said Van Papadopoulo, the programming head of Cannes Classics under the aegis of artistic director Thierry Frémaux. Altogether, a round dozen of the forty films screened in the section were digitally projected. Furthermore, Cannes Classics maintains close working connections with world-wide cinematheques to book the latest restored classics on the market: the Film Foundation (founded in 1990 by Martin Scorsese and seven other American filmmakers), Cinémathèque Française, British Film Institute, Amsterdam Film Museum. According to Papadopoulo, "the quality of digital restoration and digital projection is advancing so rapidly that the next decade will witness a corresponding digital revolution on a broad technical scale."

Tributes to Jean Renoir and James Dean were highlights of this year's Cannes Classics. The restored print of Renoir's Indian classic, The River (1951), thanks to the Film Foundation, was accompanied by still photos out of the Kobal Collection. As for the James Dean tribute, the 50th anniversary of his death was marked by Michael J. Sheridan's insightful documentary, "James Dean: Forever Young" (USA), programmed together with a restored print of Nicholas Ray's East of Eden (1955) and Elia Kazan's Rebel Without a Cause (1955), the latter digitally restored and projected.

This year, the Salle Buñuel under the roof of the Palace became the official venue of the Cannes Classics program. More often than not packed to the last seat, extra screenings had to be scheduled to handle 
the crowds. Among its many attractions were restored prints and digital projections of Luis Buñuel's Los Olvidados (Mexico, 1950), Satyajit Ray's Pather Panchali (India, 1955), Jean Renoir's La fille de l'eau (The Whirlpool of Fate, France, 1925), Michael Powell's Black Narcissus (UK, 1947), Robert Bresson's Les anges du péché (Angels of the Streets) (France, 1943), Yasujiro Ozu's There Was a Father (Japan, 1942), and the recently discovered and restored print of Sam Wood's Beyond the Rocks (USA, 1922), starring Rudolph Valentino and Gloria Swanson in their only appearance together on screen.

Just as popular were the documentaries on filmmaking. One in particular was a standout: Frederick Baker's Shadowing The Third Man (UK), crediting British novelist-screenwriter Graham Greene as a key factor in the making of Carol Reed's The Third Man (UK, 1949), the film noir classic recently voted the Best British Film of the 20th Century in a BFI poll. Other documentaries on cinema that well deserve to make the rounds of international festivals were André S. Labarthe's John Cassavetes (France), Marie Nyrerod's Ingmar Bergman Complete (Sweden), Jean-Pierre Limosin's Kitano Takeshi Unpredictable (Japan-France), and Jean-Luc Godard's video collage Moments choisis des histoire(s) du cinéma (Choice Moments in the History of Cinema, France).

\section{Special Screenings}

In the wake of a Golden Palm last year for Michael Moore's Fahrenheit 9/11 (USA), the documentary apparently became the keystone of the Special Screenings section at this year's Cannes. And for many critics the most important film of the festival was Adam Curtis's The Power of Nightmares (UK), a balanced threepart BBC documentary running just under three hours that came across as a powerful sequel to Fahrenheit 9/11. This BBC mini-series is packed with so much well researched and ably documented information on The Rise of the Politics of Fear (the film's subtitle) that it stifles the imagination. Introduced personally at Cannes by Thierry Frémaux and French director Bertrand Tavernier, Adam Curtis in The Power of Nightmares traces the myths and realities of two parallel-running harbingers of global terrorism. In the East there is Islamic Extremism preached by Egyptian theorist Said Qutb (executed in Cairo in 1966), then propagated throughout the Islamic world by his disciple Ayman Al-Zawahari (founder of the terrorist Jihad organization). In the West there is American Neo-Conservatism taught by American philosopher Leo Strauss at the University of Chicago, then integrated into government politics by Republican stalwarts Paul Wolfowitz and Richard Perle. Although the twain shall never meet, one would not exist in the public's mind without the other.

Each episode in Adam Curtis's The Power of Nightmares can pretty much stand by itself. In the first part, Baby, It's Cold Outside, he traces the roots of each movement back to the immediate postwar years. In the second part, The Phantom Victory, he chronicles the Afghanistan uprising under the Mujaihideen rebels in the 1980s. And in the third part, The Shadow in the Cave, he debunks the myth of Osama bin Laden as the mastermind of global terrorism. Of course, a documentary of this range and depth is open to probing criticism, particularly in regard to such generalizations as "neo-conservatism versus progressive liberalism" on the American political stage. Also, a continuation of the documentary series would be welcomed, if only because to demonstrate the tactics used by the Bush Administration to win last year's election via the socalled "war on terrorism" slogan. But according to Curtis, the BBC documentary has yet to be broadcast on American television.

Another documentary that drew unstinting praise from the critics was Jan Kounen's Darshan (Embracing, France-Germany-Japan). The French filmmaker, who specializes in spiritual rituals and practices, takes the viewer to Kerala in southern India to the doorstep of Amma, a healer of body and soul. Recently awarded the Gandhi-King Prize (for peace and non-violence), this short woman in her early fifties with a serene smile, radiant personality, and warm embrace for the afflicted has also been bestowed the privileged title of "mahatma" (great soul) in Hindu tradition. Although one can criticize the film on aesthetic grounds, the sheer fact is that Amma, within the short period of 15 years, has graduated from a meagre temple following in 1979 to a sweeping charitable enterprise today that now numbers hospitals, orphanages, houses for the homeless, and other benefices for the needy.

Similarly, two more striking documentaries focused on cultural traditions as mirrored in everyday life. In Fatih Akin's Crossing the Bridge - The Sound of Istanbul (Germany-Turkey) the German-born, Turkishdescent director (and jury member at Cannes) electrified audiences by taking the musical pulse of a city 
that straddles the Orient and Occident, benefiting from the creative input coming from both sides of the Bosporus. And in Rithy Panh's Les artistes du Théatre Brûlé (France-Cambodia) the director gathers a group of actors around him to work on a project that would depict the everyday reality of the Cambodian people as they struggle to rise from the tragedy of genocide to regain a sense of dignity and a restored national identity. The film can be viewed as the coda to his S21 - La machine de mort Khmère Rouge (S21 The Khmer Rouge Killing Machine, 2002), a French-Cambodian coproduction that documented the horrors experienced by the Cambodian people under Pol Pot and the brutal Khmer Rouge regime (1975-79).

\section{Un Certain Regard}

Mexican films in all the sections at Cannes were the talk of the festival. Thus it seemed only natural that Amat Escalante's Sangre (Blood, Mexico-France) should receive one of the International Critics (FIPRESCI) Awards. Leaning heavily on the Latin American liking for a daily diet of sitcoms on television (télé-novellas), this low-budget minimalist exercise in family melodrama sketches the tawdry existence of the couple Diego and Bianca, whose only relief from their menial jobs is watching the evening soap, to be followed by a bout of sex on the kitchen table. When Diego's daughter from a previous marriage arrives on the scene, the father decides to hide the news from his jealous wife until his numbed conscience can find a way out of the predicament. But when his daughter commits suicide in a seedy hotel, Diego's troubles have doubled. The dilemma leads to a surprising twist: he bags the corpse and brings it to the dump-yard, only to experience another jolting pang of conscience that will drive him in yet another direction. A debut feature with low-key acting performances, Blood introduces a talented young director to keep an eye on in the future.

The Prix Un Certain Regard, awarded by a jury headed by American director Alexander Payne (About Schmidt, Sideways), went deservedly to Cristi Puiu's Moartea Domnului Lazarescu (The Death of Mr. Lazarescu, Romania). Completed just in time to meet the festival deadline, thanks to the intervention of the Romanian Cultural Minister by awarding a subsidy grant over the heads of a stubborn film commission, The Death of Mr. Lazarescu chronicles the night route of a fatally ill retiree from his flat to one hospital after another in search of a doctor to perform the necessary emergency operation. But due to equally important needs to care for victims of a fatal highway accident, combined with registration technicalities and the general reluctance of overworked hospital staffs to accept him as a patient, Mr. Lazarescu (Joan Fiscuteanu) doesn't make it to the operating table in time. Accompanying him along the way, however, is one who does care: Mioara (Luminita Gheorghiu), the ambulance nurse, who stubbornly refuses to take no for an answer. Running at two-and-a-half-hours, and shot with a digital camera to capture the depressing blues and greys of hospital wards, The Death of Mr. Lazarescu scored as one of the high-water marks of the entire Cannes festival.

The close of the Un Certain Regard program was one of those rambunctious affairs that nearly left veteran Spanish director Benito Zambrano in the wings. First, Thierry Frémaux introduced jury president Emir Kusturica, who then took his bows with the subject of his work-in-progress documentary: Argentinean soccer legend Diego Maradona. When it finally came time for Zambrano's Habana Blues (Spain), it only confirmed once again that Havana is the ideal location setting for films about Cuban music, Cuban musicians, and the Cuban "sound" that would make a pair of childhood friends and pop stars internationally famous. Their dream is to find a Spanish (preferably woman) producer who will discover them and take them to Spain - save that Ruy also happens to have a wife with two children, a long-suffering mate who is just about fed up with her philandering husband. Tito, too, would have to leave his doting grandmother, with whom he has been living all these years in the family villa. The fun, of course, is in the build-up to the forthcoming "one last concert" before a home crowd of fans and friends and family.

\section{Directors Fortnight}

One of the most innovative filmmakers working today in Central and Eastern Europe, Lithuanian director Sarunas (better: Sharunas) Bartas, backed again by Portuguese producer Paulo Branco, returns to Cannes for the third time with an entry in the Directors Fortnight: Seven Invisible Men (Lithuania-France-Portugal). Shot on location in the Crimea in the south of the former Soviet Union, it picks up on a recurring theme that seems to haunt the director through a string of his previous films, each dealing with loners and outcasts in a shattered human condition. In Three Days (1991), awarded the Wolfgang Staudte Prize by a Forum jury 
at the Berlinale, we follow youths wandering aimlessly around Kaliningrad (formerly Koenigsberg), once the splendid Prussian capital and now an urban ruin. In Few of Us (1996) the focus is on a girl as she journeys across south-central Siberia to an isolated shack in the Sayan Mountains near the Mongolian border, a region inhabited by the native tribe of Tofolars. In Freedom (2000), shot on location in Africa and invited to Venice, the outsiders are youths involved in drug traffic and illegal boat trade.

Nothing much has changed thematically in Seven Invisible Men. After a car theft at the outset, the protagonists of different ages and backgrounds find themselves in a shack in the middle of nowhere. Each has experienced a bitter loss or simply feel robbed of their rights, whether it be marital, economic, political, or otherwise - in any case, enough to set them against the law and force them into an isolated exile. As an evening of drinking and fighting progress, it escalates to the inevitable clash. A metaphor on a fragmented and disintegrated society, the setting need not be the Crimea, but just about anywhere in ex-socialist Europe. The irony in Seven Invisible Men, however, is that the outcasts have retreated to a landscape of breathtaking beauty.

\section{Week of the Critics}

The ongoing romance between Cannes and Georgian director Otar Yoseliani (whose address is currently in Paris) goes back to 1968, when Yoseliani was introduced to the Week of the Critics audience in the Salle Bazin of the old Palais des Festivals by the late French critic Louis Marcorelles. His film, When Leaves Fall $(1966 / 68)$, a gentle tale about a lad whose nonchalant life-style reflected traditional Georgian mores rather than conformist Soviet work ethics, had already been shelved for two years with little chance for release - had not French critics put in a good word for both the director and the film with Goskino in Moscow. Shortly after its screening at the subsequently aborted Cannes festival (due to the student revolt on the streets), When Leaves Fall was awarded both the Prix Georges Sadoul and the International Critics (FIPRESCI) Prize. Taken together, these awards helped considerably to launch Yoseliani's career as an authentic auteur.

This year, the French critics invited Otar Yoseliani to serve as the parrain (godfather) at the $44^{\text {th }}$ Semaine International de la Critique. And once again, When Leaves Fall was back on the screen to the delight of visiting cineastes. The story? Niko (Ramoz Giorgobiani), a youth living in Tbilisi, is unexpectedly given an important job in a wine factory. The young man makes friends with older workers, who in return like his unorthodox manner and his respect for traditional ways of producing wine. The day comes, however, when the factory management orders him to put inferior wine on the market to meet a dubious economic plan. Niko is the only employee who refuses to go along with the scheme. He breaks a keg of wine and spills its contents onto the street. I can still remember the spontaneous applause that erupted from the audience at that Cannes screening 37 years ago.

\section{Cannes Festival History}

Every would-be critic who set foot on the Côte d'Azur has a fond memory of the Cannes film festival. Usually quite exaggerated, but always entertaining.

Some of the best accounts were written by people who had never set foot inside the Palais des Festivals. Instead, they preferred "Doing the Cannes-Cannes" or "Cruising the Croisette" - Variety-ese for enjoying the hustle-bustle and the scuttlebutt and that never-ending parade of bikinis over a long drink from the patio of the Hotel Carlton or the terrace of the Majestic.

Some of the best stories stem from the heyday of Robert Favre le Bret, Délégué Général from 1952 to 1972, when he stepped up to become President of the Festival du Film and continued to run the show from behind the scenes for a few more years.

Favre le Bret, who ran the Paris Opera in the off-season, loved the pomp and circumstance of the Cannes show. His arrival on the Croisette coincided with the change of the festival dates in 1951 from the autumn to 
the spring, to say nothing of the shock of not having a film festival at all in 1950 due to a budgetary fallout. Like any good card shark holding a good hand, he went for broke.

Of course, glamour and parties. Gina Lolobrigida was all over the 1952 festival. And why not a couple of yachts anchored in the bay? That same year, when Orson Welles won the Golden Palm for Othello, he was hosted by Alexander Korda on his yacht with Graham Greene along for good company.

He also has a knack for pulling a couple rabbits out of the hat. Believe it or not, Mack Sennett, long forgotten in Hollywood, was also a star attraction of the 1952 festival. Charlie Chaplin and Groucho were waiting in the wings. Parties, Personalities, Patriarchs of the Cinema. Put them all together, and Cannes stands for Celebrity - up to the present day.

My favourite stories about Favre le Bret? I liked the way he ran his juries. The Délégué Général had a incurable habit of sitting in on all the final jury meetings. He would give the president of the jury two votes, plus the power of the veto as a last resort. Of course, that veto was never really necessary, as the jury presidents were all French for the first decade of his tenure. Jean Cocteau, a personal friend, was hand-picked to serve in 1953, 1954, and 1957. But no matter - the French entries back then deserved most of the top awards anyway.

Once the Hollywood Studios noticed that a Golden Palm added up to très bien tickets sold at the box office, Cannes was off and running. "Doing the Cannes-Cannes" in the mid-1950s meant stuffing the ballot-box to assure a winner. By the mid-1960s, it was estimated by one insider that a Golden Palm was worth at least a million dollars in free advertising.

Probably more, publicity wise, if you throw in snapshots with les starlets. Jeanne Moreau, Sophia Loren, Brigitte Bardot, Kim Novak, Romy Schneider, Grace Kelly, Anouk Aimée, among countless others, were regulars at Cannes.

The advent of the Nouvelle Vague in the 1960s changed everything.

François Truffaut and Jean-Luc Godard, Jacques Demy and Agnès Varda, played along with the game for a while. After all, other big names had walked the thin tightrope between art and commerce before them. Directors like Luis Buñuel and Luchino Visconti, Orson Welles and Michelangelo Antonioni, all had used Cannes as the springboard to international coproduction deals and worldwide distribution.

François Truffaut once told me that a world premiere at any of the three big time film festivals - Cannes, Venice, Berlin - meant international sales across the board. More important: a guarantee that he could maintain his independence as an auteur in the fullest sense: writer, director, and hands-on producer.

Since Favre le Bret was not at all willing to share the limelight - nor that pot of gold at the end of the rainbow - with the young mavericks, the blowup at the 1968 Cannes festival was inevitable. The Quinzaine des Réalisateurs (1969), aka Directors' Fortnight, joined with the previously established Semaine de la Critique (1962) to challenge the rights of the official program in the Palace.

Out went Robert Favre le Bret in 1972, and in came Maurice Bessy.A wildcat in his own way, Bessy launched one non-competitive sections after another to stem the tide of the radicals: Perspectives du Cinéma Français, Les Yeux Fertiles, L’Air du Temps, Le Passé Composé.

Save for the Perspectives du Cinéma Français, a showcase for new French productions, no present-day Cannes colleague has ever been able to name a single film that had run in any one of these special sections, nor could he explain what the noms de guerre originally stood for.

Although Bessy's tenure was a short six years, he did break completely with the past and opened the doors to a new Cannes festival in 1978 under the aegis of Gilles Jacob, a reign that was to last for 25 years.

Ever since then, Cannes has been a grab-bag of styles and themes by filmmakers from around the world: the era of the grand-staircase festival. The biggest and richest film spectacle on earth. The Oscars, if you will, for a fortnight.

How much bigger can it get? That's for Thierry Frémaux to decide. As of 2004, he is in charge of the Official Program, while Gilles Jacob, the newly elected President of the Cannes Festival, is looking after the past. 
He wants to build a Cannes Museum: an all-year-around Cannes-Cannes for Cineastes and Festivaliers - the tourists will love it!

\section{Marché du Film - The Other Side of the Cannes Coin}

Read the introductory comments by the "Cannes troika" - president Gilles Jacob, general manager Véronique Cayla, artistic director Thierry Frémaux - about upcoming events at this year's 58th festival, and you get a glimpse of the course they have chartered for the future.

The Festival de Cannes as World Film Market.

"The Marché du Film provides, in synergy with the Festival de Cannes, ten exceptional days of encounters, exchanges, and project development in an atmosphere where there is a common desire to see independent film prosper and to encourage the production of films of quality."

In other words, Cannes intends to become the indispensable meeting place for industry professionals the world over. Since this year's Marché de Film welcomed over 9,000 buyers, sellers, and producers, the number of market screenings and related events has nearly doubled over last year.

"It's a sign of the vitality of world film production," commented Gilles Jacob.

"The development of digital technology has enabled the emergence of a form of cinema that is easier to produce," underscored Thierry Frémaux.

"This year, we are opening a new theatre, called Cinéma du Monde," to promote the diversity of world cinema at a time when some fear it is seriously at risk from the globalization of the film industry," added Véronique Cayla.

On May 13, all eyes were on the grand opening of the new Cinéma du Monde theatre. Designed by Patrick Blouchain and located in the Village International Pantiero, this venue - "a prototype of a new generation of contemporary theatres" - will focus on the cinematographies from seven countries on the five scattered continents of the globe. Each country is free to compose its own program.

Opening with Morocco, the daily world tour then moved on to South Africa, Mexico, Austria, Peru, Sri Lanka, and the Philippines.

Since three of these countries - Mexico, Austria, and Sri Lanka - also have one or more films in the Official Selection, the idea was to shed light on "cultural identity" in the world film market.

At the same time, this "Tous les Cinémas du Monde" program ran parallel to presentations in "L'Atelier du Festival" and "La Rencontre du Festival" - three new festival additions geared principally to catch the eye of film market professionals.

L'Atelier du Festival, an offshoot of the Cinéfondation competition for film students, had been founded to help talented young filmmakers bring their projects to the screen.

For the first year, 18 young filmmakers from around the world were invited to Cannes to pitch their projects to industry professionals, to wit: Fatmir Koci (Albania), Ulricke vn Ribbeck (Germany), Lisandro Alonso (Argentina), Joachim Lafosse (Belgium), Aida Bejic (Bosnia), Yang Chao (China), Celia Galan Julve (Spain), David Lambert (France), Imunga Ivanga (Gabon), Nariman Turebayev (Kazakhstan), Som Ock Southiponh (Laos), Gerardo Naranjo (Mexico), Tawfik Abu Wael (Palestine), Encina Paz (Paraguay), Josue Mendez (Peru), Vladimir Perisic (Serbia), Mahamat Salen Haroun (Chad), and Ryan Eslinger (USA).

The objective of the Atelier? "At the end of the festival," predicted Véronique Cayla, "most of these projects should become realities to be discovered in a year or two - at Cannes, for example!"

As for La Rencontre du Festival, this "encounter" brought together filmmakers from the various festival juries to reflect on the current and future role of film festivals. Meeting on May 10, the day before the opening ceremony, this august assembly numbers Emir Kusturica (president of the international jury), Alexander Payne, Fatih Akin, Patrick Chamoiseau, Eduardo Antim, John Woo, Gilles Marchard, and Benoit Jacquot. 
One of the problems considered by La Rencontre du Festival is the volume of films currently viewed by festival selection committees. At Cannes, for instance, 1,540 feature films from 97 countries were submitted, an increase of $16 \%$ over last year (and double the submissions of five years ago).

The Cannes Selection Committee boiled those submissions down to 53 films from 28 countries in the Official Program, of which 50 are world premieres and eleven film debuts (one in the competition). As for the remaining thousand on the submission list, many were earmarked for the L'Atelier du Festival and the Marché du Film.

The buzz at Cannes? The burning question was whether or not the old-style film market is on their way out, to be replaced in the future by a virtual film market.

Territories are often sold in advance. Digital and DVD projection is in. Film prints need not be shipped from festival to festival, from market to market.

Furthermore, not every producer, distributor, and sales agent can afford a trip to Cannes for the Biggest Film Show on Earth.

Yet no one I talked to at Cannes wants to miss it.

\section{Author Information}

Ron HOLLOWAY (1933-2009) was an American critic, film historian, filmmaker and correspondent who adopted Europe as his home in the early fifties and spent much of his life in Berlin. He was an expert on the study of German cinema and against all odds produced, with his wife Dorothea, the journal German Film, keeping us up-to-date with the work of directors, producers and writers and the showing of German films around the world.

In 2007, Ron Holloway and his wife were awarded the Berlinale Camera Award. Ron also received the Bundesverdienstkreuz (German Cross of Merit), Polish Rings, Cannes Gold Medaille, the American Cinema Foundation Award, the Diploma for Support of Russian Cinema and an honorary award from the German Film Critics' Association.

Ron was also a valued contributor to Kinema for the past fifteen years. 